\title{
Islam and Democracy after the Arab Spring
}

\author{
John L. Esposito, Tamara Sonn, and John O. Voll \\ New York: Oxford University Press, 2016. 320 pages.
}

The debate on Islam and democracy is one of the most heated in academia, engaging both Muslims and non-Muslims, normative and analytic approaches. It also takes place on two levels: political-theoretical determinations of the compatibility or incompatibility between Islam and democracy, and empirical discussions over how much Muslims (or Muslim societies) have modernized or resisted modernization. These debates have yielded a vast literature, to which the present book under review is a significant addition. It presents an overview of the historical developments regarding Islam and democracy and anticipates future trends in seven major countries: Turkey (Chapter 2), Iran (Chapter 3), Pakistan (Chapter 4), Indonesia (Chapter 5), Senegal (Chapter 6), Tunisia (Chapter 7), and Egypt (Chapter 8 ). The book also includes an introductory chapter (Chapter 1) and a conclusion (Chapter 9).

The introduction provides a literature review and brief overview of the developments that served as immediate causes of Arab Spring in various countries. Various analysts have cited factors including a 'youth bulge' (a majority of the population in the Muslim world is comprised of citizens under 30), poverty, unemployment, repressive monarchial regimes, and the mass provocative events of self-immolation (as of Bouazizi in Tunisia) or killing (as of Khalid Said in Egypt) or torture (as of graffiti artists in Syria). Other analysts are of the opinion that the Muslim countries were at last catching up to the rest of the democratic world. This book considers these factors, presenting a critical assessment of Huntington's equation of modernization with secularization and his equation of rejecting secularism 
with rejecting democracy. Drawing on a number of Muslim scholars' understanding of democracy and its relationship with Islam, the authors foreground the complexity of the issue, ultimately making a case for 'multiple democracies' (echoing Eisenstadt's 'multiple democracies'). They argue that in many Muslim countries, the Islamists took recourse to democracy in their struggle against their respective dictatorial and monarchial regimes.

The second chapter focuses on democratic transitions in Turkey's secular state. The discussion ranges from 'origins of Turkey's secular state' through 'the re-emergence of Islam in Turkish politics' to 'attempted military coup' and 'the clash of AKP with the Gülen Movement.' Erdogan's advocacy of democracy in Egypt and Tunisia post-Arab Spring is also discussed. Turkey's democratic transition in the command of Islamists is an illustrative empirical refutation of the theory that Muslims (especially Islamists) are not amenable to democracy. The authors generously remark: "Despite its critics [sic] charges, during its brief period in power, the WP did not impose an Islamic state but created a more democratic Turkey with space for religion and implemented socio-economic reforms, a more just and equitable society, and an end to corruption and nepotism" (48). Turkey does not witness a case of Islam versus democracy so much as a case of Islam versus militant secularism. Towards the end of the chapter, the authors make meaningful suggestions for both the Turkish government as well as the opposition (the military, secular elites, and others). While they recommend the former strive for a more pluralist political culture and values of power sharing and respectful guarantee of political opposition, the latter should accept the challenge of a 'loyal opposition' instead of conspiring for the toppling of a democratically elected government. In Turkey, it is not the Islamists but the militant secularists who have continuously hindered the democratic process.

In the third chapter, concerned with the state of democracy in Iran, the authors insightfully observe the preference, on the part of the capitalist West, for 'semi-democratic authoritarian regimes' rather than fully democratic forces, in order to safeguard various financial interests. In the words of the authors: "Better to support an unpopular regime that protects US investments than risk populist governments that may turn against US interests" (50). Infamously, this policy led to US participation in a clandestine operation to overthrow Mohammad Mosaddegh, the first democratically chosen prime minister of Iran, and to reinstate the authoritarianism of the Shah. The economic champions of the world who, unfortunately, claim to be the champions of democracy, too, exploit these constructs; this is de- 
mocracy as dictated by realpolitik, echoing the Foucauldian account of the relationship between power and knowledge (in this case, of the signifier 'democracy'). While Iran had witnessed something like Arab Spring much before in 1909, in the aftermath of the Arab Spring (in the elections of summer 2013) it experienced a higher voter turnout and the election of progressive candidate Hassan Rouhani.

The fourth chapter portrays the trajectory of democratization in $\mathrm{Pa}$ kistan, where the realization of democracy has time and again failed due to successive military takeovers. The nexus between the army feudal elite and tribal chiefs serves as the main impediment to the democratization of governance (79). Despite Pakistan's continued struggle for democracy, the fundamental question is not about the compatibility of Islam and democracy or a choice between Islam and secularism but the achievement of good governance inspired by Islamic ideals. This is testified by its founding documents like the 1949 Objectives Resolution. Good governance and political legitimacy, in the case of Pakistan, can be measured or assessed in terms of the realization of the higher objectives (maqa șid) of Islamic law. The authors aptly remark: "The continued calls for Islamic governance in Pakistan reflect just this sort of struggle-the struggle to fulfill Pakistan's Islam-inspired objectives of good governance, measured in terms of the well-being of even the weakest members of society" (114).

The Indonesian transition from authoritarian military rule to democracy is unique in that it occurred without "inciting reverse waves or eliminating important groups of people" (148). Likewise, Senegal emerged as a relatively successfully democratized country, where democratization was disrupted neither by military intervention nor by ethnic tribal affiliations. Rather, the forces that have played a disruptive role regarding democratization at other places have transformed themselves, in case of Senegal, into a tolerant pluralistic political whole resulting in the smooth transfer of power from the ruling party to its successors. These forces continue to impact the Senegalese political system, but they operate in 'new ways' in the changing political milieu of the present century.

In Tunisia, the cradle of Arab Spring, rapid democratization was a success despite all odds. This can be attributed to strong civil society organizations, the military's professionalism, and the moderation of Ghannouchi and the Islamist Ennahda party, which is characterized by flexibility and leniency. However, the latest positions taken by Ghannouchi need careful and critical evaluation to understand his objectives as well as to anticipate the future of democracy in Tunisia. The challenge before Tunisia is not 
strife between Islamists and secularists but how governments can manage to adopt a policy of inclusion rather than exclusion and the loyalty of opposition parties. The last chapter of the book focuses on the developments in Egypt that led to the democratic election of Mohammed Morsi followed by the reverse wave of the military coup, proving the path to democratization "rocky, disappointing, and treacherous" (234).

The book is an excellent, informative, and laudable account of democratization in seven Muslim countries and the consequent struggles between different forces (Islamist, secular, military, ethnic, etc.). These seven case studies help us understand the complex roles of the military, ethnic groups, and various interest blocs in the process of democratization. In sum, this title is an indispensable work for scholars and students of Political Science, International Relations, Political Islam, etc. However, what remains unattended (as is so frequently the case with advocates of democracy as well as with analysts of the Islam-democracy relationship) is why democracy should be considered, in the first place, to be the best model of governance. Does democracy herald the end of human reasoning and reflection in the realm of governance? Why is oppression unconditionally related to monarchial regimes while the atrocities perpetrated by democratic states are explained away in the name of legitimacy and national sovereignty? A final point of note lies in the curious contrast that when Islamists mobilize the Muslim masses against the West or their secular governments, they hold democracy to be antagonistic to Islam, but in their struggle against Muslim dictators and monarchs, they argue for the compatibility of democratic party politics with Islam.

Gowhar Quadir Wani $\mathrm{PhD}$ candidate, Dept of Islamic Studies Aligarh Muslim University 